\title{
The Effect of Brand Image and Price Changes on the Purchase Decision of Cement Products in the City of Palembang
}

\author{
Ahmad Faisal Ramadhan \\ Master of Management, Sriwijaya University, Palembang, Indonesia \\ Corresponding author email: ahmadixal@gmail.com

\section{Zakaria Wahab} \\ Lecturer of Magister Management, Economic Faculty, Sriwijaya University, Palembang, Indonesia \\ Email: zkwahab01@gmail.com \\ Muchsin Saggaf Shihab \\ Lecturer of Magister Management, Economic Faculty, Sriwijaya University, Palembang, Indonesia \\ Email: muchsin.shihab@bakrie.ac.id \\ Marlina Widiyanti \\ Lecturer of Magister Management, Economic Faculty, Sriwijaya University, Palembang, Indonesia \\ Email: marlinawidiyanti68@yahoo.co.id
}

\begin{abstract}
This study aims to determine the effect of brand image and price changes on the purchasing decisions of cement products in Palembang (study on consumers of Baturaja cement products in Palembang). The population in this study is all consumers of cement products in Palembang in 2021. With the criteria for determining the sample, the sample in this study was 150 respondents. The multiple linear regression analysis results show that brand image has a positive and significant effect on purchasing decisions for Baturaja cement products. Price changes have a positive and significant effect on purchasing decisions for Baturaja cement products. Brand image, PT Semen Baturaja (Persero), Tbk should maintain the good image of PT Semen Baturaja (Persero), Tbk among the public because its status as a state-owned company does not guarantee to be the consumer's first choice. Price changes: It is necessary to make regular price adjustments with cement competitors because the price difference is a little more expensive, so consumers will switch to products from other companies.
\end{abstract}

Keywords---brand image, cement products, price change, purchase decision.

\section{Introduction}

The condition of the national cement industry before 2015 can be very stable, where cement demand has increased by 10-12\% every year (Indonesian Cement Association Data, 2015). This was used as a reference for local cement producers to increase cement production capacity, especially at that time, there were only four big players in the national cement industry, namely Semen Indonesia, Semen Holcim, Semen Tiga Roda, and Semen Baturaja. This condition makes producers benefit not only because they can dictate prices but also because they create a captive market, where potential consumers face a minimal number of competitive suppliers. The consumer's only choice is to buy what is available or not make a purchase.

The growth of the cement market in Indonesia has changed since the beginning of 2015 due to an increase in national cement production capacity, which is not matched by an increase in demand, resulting in an oversupply. The decline in demand for cement was also caused by the weakening of the world economy, which affected the weakening of the national economy so that the level of public consumption decreased. The declining level of 
consumption can be seen from the declining inflation. Inflation in 2015 fell significantly by $5 \%$ compared to inflation in 2014 of $3.35 \%$, which was also the lowest inflation in the last five years.

Changes in the national cement industry conditions also occurred due to the increasing number of new entrants in the national cement industry. Until now, 15 companies have been involved in the national cement industry. As a result, in the 2015-2016 period, there was an additional production capacity of 34 million tons from 13 new factories, bringing the total national production capacity to 93 million tons per year (Daily Investor, 01 October 2016). The peak was in 2019; the national cement production capacity increased by almost 16 million tons, bringing the total national production capacity to 108.75 tons per year.

The impact of oversupply began to be felt in 2017. Based on data from the Indonesian Cement Association, national cement sales during the first semester of 2016 were 29.4 million tons, a slight decrease from the first semester of 2017. This was due to the overcapacity of cement production capacity, which continued to grow to 93 million tons. Million tons per year, while the national demand is estimated to be only around 65 million tons. The peak of the national cement overcapacity occurred in 2019, which increased to 40 million tons per year. In 2020, Indonesia and all countries worldwide were facing the COVID-19 pandemic; this is also the cause of the decline in cement demand.

As a result of the COVID-19 pandemic, the cement industry experienced a 10\% decline in national demand from 70 million tons in 2019 to 63 million tons in 2020, and cement market conditions experienced an oversupply of \pm 53 million tons so that the national cement factory utilization was $54 \%$. Along with the decline in national cement demand, the impact on the Semen Baturaja market area, Southern Sumatra (Sumbagsel) decreased cement demand$4.1 \%$ or to 5.99 million tons of cement in 2020, and in the main Semen Baturaja market area, demand decreased deeper cement where cement demand in South Sumatra Province only reached 2.10 million tons of cement in 2020 or down - 7.2\% from 2019.

Pandemic Conditions COVID-19 oversupply cement industry led to increased competition between manufacturers of cement. This causes cement producers to seek new market shares outside their primary market to maintain production utility. Each producer began to market their products to competitors' primary markets, resulting in price wars between fellow cement producers; this was done because each company carried out various strategies to retain consumers and tried to win new consumers from competing companies through price wars with a change strategy. The price follows the price change strategy of the leading producers in a cement market area (Müller et al., 1990; Puller \& Greening, 1999).

Price wars as a strategy to seize consumers in the new cement market are starting to be felt by one of the national cement producers, namely Semen Baturaja, where the primary market for Semen Baturaja is the Sumbagsel area, especially in Palembang City, which is continuously penetrated by competitor cement products with a price change strategy following each time (Pourchez et al., 2006). Changes in Semen Baturaja as the leading cement producer in the South Sumatra cement market, especially in the city of Palembang.

The decline in sales performance followed by a decrease in market share due to the price war strategy changes in prices followed the price of the major producers in a market cement in particular market Semen Balfour in the city of Palembang in fear reposition the brand image (brand image) of Semen Balfour strong cement market town Palembang which was formed during the captive market period because nowadays consumers are faced with many choices of cement brands with competitive prices (Cretu \& Brodie, 2007; Michel \& Rieunier, 2012).

The current price competition is the latest condition in the cement industry so no one has researched changes in the price of cement products as a result of price competition as one of the variables that influence purchasing decisions other than the brand image that has been formed during the captive period (Lien et al., 2015). Market. Previous studies in the cement industry, especially Semen Baturaja, still discuss brand image on customer loyalty, such as research from Santri et al. (2014), found that brand image has a positive and significant effect on customer loyalty to cement brands. King stone. Meanwhile, from research discussing prices, it is still limited to price perceptions related to promotions, not price changes due to price competition related to the brand image that has been formed so far in the cement industry before the price war, as in the research of Xia et al. (2010), found the results of the analysis in this study indicate that the price and promotion variables have a positive and significant effect on purchasing decisions (Huang \& Benyoucef, 2017; Karimi et al., 2018; Chen et al., 2017). The independent variable, which has a positive value, the significant and dominant influence, is the price on cement purchasing decisions at PT. Semen Baturaja (Persero), Tbk. This research is intended to measure the extent of brand image and price competition on the level of sales of Semen Baturaja in the Palembang City area (Ferdani et al., 2020). 


\section{Research Methods}

The source of data used in this study is primary data collected by themselves when researching by distributing questionnaires to shops selling Baturaja cement in Palembang in 2021. The population in this study was all consumers of cement products in Palembang in 2021. The sample in this study was consumers who purchased cement in Palembang with several criteria for determining the sample, so the number of samples used in this study was 150 respondents.

\section{Individual parameter significance test results (t-Test)}

- The brand image variable (X 1 ) has a beta value of 0.188 with a significant value of 0.001 , more diminutive than 0.05 . This shows that the brand image variable has a positive and significant influence on the purchasing decision of Baturaja cement in the city of Palembang. This proves that the first hypothesis on the brand image variable has a positive and significant effect and can be accepted.

- The price change variable (X 2 ) has a beta of 0.694 with a significance value of 0.000 , more diminutive than 0.05. This shows that the variable price changes have a positive and significant influence on purchasing cement Baturaja in the city of Palembang. This proves that the second hypothesis on the price change variable has a positive and significant effect and can be accepted.

\section{Results and Discussion}

This study indicates that the brand image described through the dimensions of brand identity, brand personality, brand associations, brand attitudes and behavior, brand benefits, and advantages shows that the Baturaja cement brand image already has a good image in the community (Fadila et al., 2021). This makes consumers more interested in using Baturaja cement products compared to cement from other companies. This is indicated by the results of the questionnaire distribution, which shows that the Semen Baturaja indicator is a state-owned company showing the lowest score. Based on interviews with several respondents in the field, consumers say that the image as a stateowned company does not guarantee consumer interest in making purchases, especially with the many competitors of other cement companies, which makes consumers not question the origin of the product they want to buy.

Brand image has a positive and significant effect on purchasing decisions. The results of this study are in line with the results of research from (Rizki et al., 2019), (Tirtaatmaja et al., 2019), (Saing et al., 2019), (Armayani and Jatra, 2019), (Amalia \& Nurseto, 2019), (Kurniawan \& Budiatmo, 2020), (Mahanani, 2018); (Kurniawan et al., 2018); (Hanifati \& Waloejo, 2019); (Prasetya et al., 2018), (Pulukadang et al., 2019), (Pratama \& Santoso, 2018), (Soebakir et al., 2018), (Adyanto \& Santosa, 2018), (Fatmawati \& Soliha, 2017), (Saraswati \& Rahyuda, 2017), (Venessa, 2017), (Reven \& Ferdinand, 2017), (Madyan \& Tiarawati, 2014), found that brand image has a positive and significant effect on purchasing decisions.

The results of this study indicate that price changes are described through the dimensions of affordability, price conformity with product quality, price competitiveness, price suitability with benefits, price sensitivity (Hamilton, 1996). In the Baturaja cement indicator, consumers still choose if the price is high IDR. 10,000 indicates the lowest score. This shows that the price competition is getting tighter among cement producers in Indonesia, with the need for price adjustments with other cement competitors. The slightest price difference makes consumers prefer cheaper products, especially with the same product quality.

Price changes have a positive and significant effect on purchasing decisions. These results are in line with research results from (Rizki et al., 2019), (Tirtaatmaja et al., 2019), (Inayah et al., 2019), (Armayani \& Jatra, 2019), (Amalia \& Nurseto, 2019), (Kurniawan \& Budiatmo, 2020), (Hanifati \& Waloejo, 2019), (Maindoka et al., 2018), (Pratama \& Santoso, 2018), (Soebakir et al., 2018), (Adyanto \& Santosa, 2018); (Fatmawati \& Soliha, 2017); (Saraswati \& Rahyuda, 2017), (Venessa, 2017), (Reven \& Ferdinand, 2017), (Madyan \& Tiarawati, 2014), found that price had a positive and significant effect on purchasing decisions.

\section{Conclusions}

Brand image and price changes have a positive and significant effect on purchasing decisions for Baturaja cement products in Palembang.

\section{Acknowledgments}

The author expresses his deep gratitude to the academic parties who have provided support in the form of feedback. 
References

Adyanto, B. C., \& Santosa, S. B. (2018). Pengaruh Kualitas Layanan, Brand Image, Harga Dan Kepercayaan Produk Terhadap Keputusan Pembelian (Studi Layanan E-Commerce Berrybenka. com). Diponegoro Journal of Management, 7(1), 10-29.

Amalia, E., \& Nurseto, S. (2019). Pengaruh Harga Dan Citra Merek Terhadap Keputusan Pembelian Smartphone Samsung (Studi pada Pengguna Smartphone Samsung di Kota Semarang). Jurnal Ilmu Administrasi Bisnis, 8(4), 91-97.

Armayani, A., \& Jatra, I. M. (2019). Peran Brand Image Memediasi Promosi Dn Harga Terhadap Keputusan Pembelian Smartphone Samsung di Kota Denpasar. E-Journal Manajemen, 8(8), 5222-5239.

Chen, A., Lu, Y., \& Wang, B. (2017). Customers' purchase decision-making process in social commerce: A social learning perspective. International Journal of Information Management, 37(6), 627-638. https://doi.org/10.1016/j.jijinfomgt.2017.05.001

Cretu, A. E., \& Brodie, R. J. (2007). The influence of brand image and company reputation where manufacturers market to small firms: A customer value perspective. Industrial marketing management, 36(2), 230-240. https://doi.org/10.1016/j.indmarman.2005.08.013

Fadila, D., Wahab, Z., Isnurhadi, I., \& Widiyanti, M. (2021). The effect of brand image, brand ambassador, and product quality on the purchase decision of Mustika Ratu products: (study on Sriwijaya University students). International Journal of Social Sciences, 4(1), 182-189. https://doi.org/10.31295/ijss.v4n1.1657

Fatmawati, N., \& Soliha, E. (2017). Kualitas Produk, Citra Merek Dan Persepsi Harga Terhadap Proses Keputusan Pembelian Konsumen Sepeda Motor Matic "Honda". Jurnal Manajemen Teori dan Terapan| Journal of Theory and Applied Management, 10(1), 1-20.

Ferdani, A. R., Wahab, Z., Shihab, M. S., \& Widiyanti, M. (2020). Effect of service quality, tariff perception and brand image toward costumer satisfaction. International Journal of Social Sciences,3(1), 90-99. https://doi.org/10.31295/ijss.v3n1.168

Hamilton, J. D. (1996). This is what happened to the oil price-macroeconomy relationship. Journal of monetary economics, 38(2), 215-220. https://doi.org/10.1016/S0304-3932(96)01282-2

Hanifati, F., \& Waloejo, H. D. (2019). Pengaruh harga, brand image, dan kualitas pelayanan terhadap keputusan pembelian (Studi kasus gracia skin clinic Semarang). Jurnal Ilmu Administrasi Bisnis, 8(4), 60-66.

Huang, Z., \& Benyoucef, M. (2017). The effects of social commerce design on consumer purchase decision-making: An empirical study. Electronic Commerce Research and Applications, 25, 40-58. https://doi.org/10.1016/j.elerap.2017.08.003

Inayah, D., Zulkarnain, Z., \& Garnasih, R. L. (2019). Analisis Pengaruh Kualitas Produk Dan Harga Terhadap Brand Image Dan Keputusan Pembelian Sepeda Motor Yamaha Mio Pada PT. Alfa Scorpii Kota Pekanbaru. Jurnal Tepak Manajemen Bisnis, 11(3).

Karimi, S., Holland, C. P., \& Papamichail, K. N. (2018). The impact of consumer archetypes on online purchase decision-making processes and outcomes: A behavioural process perspective. Journal of Business Research, 91, 71-82. https://doi.org/10.1016/j.jbusres.2018.05.038

Kurniawan, F., Arifin, Z., \& Fanani, D. (2018). Pengaruh Citra Merek Terhadap Keputusan Pembelian (Survei Kepada Para Siswa Sman 15 Surabaya Kelas XII Yang Menggunakan Laptop Ber Merek Asus). Jurnal Administrasi Bisnis, 56(1), 65-74.

Kurniawan, M. A., \& Budiatmo, A. (2020). Pengaruh Citra Merek dan Harga Terhadap Keputusan Pembelian Toyota Rush Melalui Minat Beli Sebagai Variabel Intervening (Studi Pada Konsumen Toyota Rush di Nasmoco Kota Semarang). Jurnal Ilmu Administrasi Bisnis, 9(4), 548-553.

Lien, C. H., Wen, M. J., Huang, L. C., \& Wu, K. L. (2015). Online hotel booking: The effects of brand image, price, trust and value on purchase intentions. Asia Pacific Management Review, 20(4), 210-218. https://doi.org/10.1016/j.apmrv.2015.03.005

Madyan, I. S., \& Tiarawati, M. (2014). Pengaruh Kualitas Produk, Citra Merek, dan Harga terhadap Keputusan Pembelian Ponds Flawless White. BISMA (Bisnis dan Manajemen), 6(2), 98-105.

Mahanani, E. (2018). Pengaruh Citra Merek, Kualitas Produk, Harga Dan Gaya Hidup Terhadap Keputusan Pembelian Produk Mataharimall. Com. Journal Ikhraith Humaniora, 2(1), 53-61.

Maindoka, L. F., Tumbel, A., \& Rondonuwu, C. (2018). Analisis Pengaruh Citra Merek, Harga Dan Desain Produk Terhadap Keputusan Pembelian Mobil Nissan Grand Livina Pada PT. Wahana Wirawan Manado. Jurnal EMBA: Jurnal Riset Ekonomi, Manajemen, Bisnis dan Akuntansi, 6(3).

Michel, G., \& Rieunier, S. (2012). Nonprofit brand image and typicality influences on charitable giving. Journal of business research, 65(5), 701-707. https://doi.org/10.1016/j.jbusres.2011.04.002 
Müller, U. A., Dacorogna, M. M., Olsen, R. B., Pictet, O. V., Schwarz, M., \& Morgenegg, C. (1990). Statistical study of foreign exchange rates, empirical evidence of a price change scaling law, and intraday analysis. Journal of Banking \& Finance, 14(6), 1189-1208. https://doi.org/10.1016/0378-4266(90)90009-Q

Pourchez, J., Govin, A., Grosseau, P., Guyonnet, R., Guilhot, B., \& Ruot, B. (2006). Alkaline stability of cellulose ethers and impact of their degradation products on cement hydration. Cement and Concrete Research, 36(7), 1252-1256. https://doi.org/10.1016/j.cemconres.2006.03.028

Prasetya, E. G., Yulianto, E., \& Sunarti, S. (2018). Pengaruh Brand Image Terhadap Keputusan Pembelian (Survei Pada mahasiswa Fakultas Ilmu Administrasi Bisnis Progam Studi Administrasi Bisnis angkatan 2014 konsumen Air Mineral Aqua). Jurnal Administrasi Bisnis, 62(2), 214-221.

Pratama, D. W., \& Santoso, S. B. (2018). Pengaruh Citra Merek, Kualitas Produk dan Harga Terhadap Keputusan Pembelian melalui Kepercayaan Konsumen pada Produk Stuck Original. Diponegoro Journal of Management, 7(2), 139-149.

Puller, S. L., \& Greening, L. A. (1999). Household adjustment to gasoline price change: an analysis using 9 years of US survey data. Energy economics, 21(1), 37-52. https://doi.org/10.1016/S0140-9883(98)00006-1

Pulukadang, M. W., Mananeke, L., \& Roring, F. (2019). Pengaruh Brand Image Terhadap Keputusan Pembelian Produk Herbalife (Studi Kasus Pada Lima Nutrition Club Manado). Jurnal EMBA: Jurnal Riset Ekonomi, Manajemen, Bisnis dan Akuntansi, 6(3).

Reven, D., \& Ferdinand, A. T. (2017). Analisis Pengaruh Desain Produk, Kualitas Produk, Harga Kompetitif, dan Citra Merek Terhadap Keputusan Pembelian (Studi Pada Pelanggan Nesty Collection Jakarta). Diponegoro Journal of Management, 6(3), 152-164.

Rizki, A. G., Hidayat, K., \& Rahma Devita, L. D. (2019). Pengaruh citra merek dan harga terhadap keputusan pembelian pada e-commerce Shopee Indonesia (Survei pada mahasiswa S1 fakultas Ilmu Administrasi Universitas Brawijaya angkatan 2015/2016 dan 2016/2017 yang membeli barang secara online di ecommerce). Jurnal Administrasi Bisnis, 72(2), 49-56.

Saing, S. M., Alam, S., \& Maming, J. (2019). Pengaruh Strategi Pemasaran Dan Brand Image Terhadap Kepuasan Dan Keputusan Pembelian Produk "Kita" Perum Bulog Subdivre Makassar. Hasanuddin Journal of Management, 1(1), 1-8.

Santri, B., Wahab, Z., Widiyanti, M., \& Shihab, M. S. (2014). Effect of Image and Brand Trust on Loyalty of Cement Baturaja Consumers. Growth, 60, 3-3.

Saraswati, A. R., \& Rahyuda, I. K. (2017). Brand Image Memediasi Kualitas Produk dan Harga dengan Keputusan Pembelian Smartphone Apple di Kota Denpasar (Doctoral dissertation, Udayana University).

Soebakir, B. D., Lumanauw, B., \& Roring, F. (2018). Pengaruh Brand, Harga dan Kualitas Pelayanan Terhadap Keputusan Pelanggan Membeli di Kedai Kopi Gudang Imaji Manado. Jurnal EMBA: Jurnal Riset Ekonomi, Manajemen, Bisnis dan Akuntansi, 6(4).

Tirtaatmaja, D. I., Tampi, J. R., \& Punuindoong, A. Y. (2019). Pengaruh Brand Image Dan Harga Terhadap Keputusan Pembelian Mobil Toyota Avanza Pada Pt. Hasjrat Abadi Tendean Manado. Jurnal Administrasi Bisnis (JAB), 9(1), 90-95.

Venessa, I. (2017). Pengaruh Citra Merek (Brand Image) Dan Harga Terhadap Keputusan Pembelian Konsumen (Survei Pada Mahasiswa Program Studi Administrasi Bisnis Fakultas Ilmu Administrasi Universitas Brawijaya Malang Tahun Angkatan 2013/2014 Dan 2014/2015 Pengguna Kartu Pra-Bayar Simpati) (Doctoral dissertation, Universitas Brawijaya).

Xia, L., Kukar-Kinney, M., \& Monroe, K. B. (2010). Effects of consumers' efforts on price and promotion fairness perceptions. Journal of Retailing, 86(1), 1-10. https://doi.org/10.1016/j.jretai.2009.10.003 